\title{
Article \\ Impact of Pheidole fallax (Hymenoptera: Formicidae) as an Ecosystem Engineer in Rehabilitated Coal Mine Areas
}

\author{
Yamileth Domínguez-Haydar ${ }^{1}{ }^{(\mathbb{B}}$, Bleydis Paola Gutierrez-Rapalino $\left.{ }^{1}{ }^{(}\right)$, Yair Barros-Torres ${ }^{1}$, Juan José Jiménez ${ }^{2} \mathbb{D}^{\circledR}$, \\ Sergio Esteban Lozano-Baez ${ }^{1, *} *$ and Mirko Castellini ${ }^{3}$ (i)
}

Citation: Domínguez-Haydar, Y.; Gutierrez-Rapalino, B.P.;

Barros-Torres, Y.; Jiménez, J.J.; Lozano-Baez, S.E.; Castellini, M. Impact of Pheidole fallax

(Hymenoptera: Formicidae) as an Ecosystem Engineer in Rehabilitated Coal Mine Areas. Appl. Sci. 2022, 12, 1573. https://doi.org/10.3390/ app12031573

Academic Editor: Claudio De Pasquale

Received: 8 January 2022

Accepted: 30 January 2022

Published: 1 February 2022

Publisher's Note: MDPI stays neutral with regard to jurisdictional claims in published maps and institutional affiliations.

Copyright: (C) 2022 by the authors. Licensee MDPI, Basel, Switzerland. This article is an open access article distributed under the terms and conditions of the Creative Commons Attribution (CC BY) license (https:// creativecommons.org/licenses/by/ $4.0 /)$
1 Department of Biology, Universidad del Atlántico, Carrera 30 Número 8-49, Puerto Colombia 081001, Colombia; yamilethdominguez@mail.uniatlantico.edu.co (Y.D.-H.); bleydis1804@gmail.com (B.P.G.-R.); ybarrostorres@gmail.com (Y.B.-T.)

2 Biodiversity Conservation and Ecosystem Restoration Department, Pyrenean Institute of Ecology (ARAID/IPE-CSIC), 22700 Jaca, Spain; jjimenez@ipe.csic.es

3 Council for Agricultural Research and Economics, Research Centre for Agriculture and Environment (CREA-AA), Via C. Ulpiani 5, 70125 Bari, Italy; mirko.castellini@crea.gov.it

* Correspondence: sergiolozano1391@gmail.com
Abstract: Pheidole fallax is one the most abundant ants in sites where coal mines have undergone rehabilitation and in forests without mine intervention. The impact that this species may have as an ecosystem engineer needs to be assessed. We aimed to test whether $P$. fallax nests have an effect on soil chemical properties, to characterize the organic debris found in the refuse piles, and to describe nest architecture as proxy of the bioturbation effect. The study was carried out in a coal mine in Colombia, in sites with 16 and 20 years of rehabilitation. Samples were taken from inside the nests, from the external refuse pile, and from a control treatment one meter away from the nest. The three sample types were subjected to chemical analysis and near-infrared spectra (NIRS). The biomass of items from the 20-year site was significantly greater, and P. fallax use food resources of different trophic levels, with arthropods and seeds being the main items in their diet. The NIRS analysis enabled us to distinguish the origin of the sample: refuse pile, interior of nest, or control soil. No statistical differences were found between the soil of the nests and control soil. High contents of organic matter and other parameters contributed to the soil nutrient pool through accumulation of organic debris in the refuse piles. Nest molds presented an asymmetric architecture, with mean volume ranging from 30 to $105.7 \mathrm{~cm}^{3}$ and an average of 11.8 chambers per nest. The construction and maintenance of nests may play an important role in the reestablishment of ecological and hydrological processes, such as bioturbation and water infiltration, respectively.

Keywords: ant nest architecture; bioturbation; forest restoration; mine reclamation; NIRS

\section{Introduction}

Open-pit coal mining is one of the human activities with the greatest environmental and social impact since it generates changes in land use in large areas, affecting ecosystems and biodiversity [1]. Ecological rehabilitation of these areas involves the restoration of ecosystem processes that sustain the provision of goods and services, particularly those generated by the soil [2,3]. A basic component that must be evaluated in soil under restoration processes is the soil macrofauna [4], which plays a fundamental role in maintaining ecosystem functions [5].

Ants, termites, and earthworms are considered ecosystem engineers because they affect soil structure by the formation of soil aggregates and pores, and by the production of physical structures that can modify the availability of and access to resources for other organisms [6]. Ants are particularly important regulators of soil processes on different temporal and spatial scales [7]. For example, the bioturbation generated during the construction of nests can change soil physical properties, affecting the soil porosity and water 
flow [8,9]. Additionally, nest construction modifies the chemical composition of the soil by incorporating nutrients and organic matter from parts of insects, feces, and seeds, which act at different temporal and spatial scales [10-12]. These processes contribute to soil quality improvement in rehabilitated areas; however, in the mine context, ants have been mainly recognized as bioindicators [13-16]. Nevertheless, it is necessary to know the importance of ants as ecosystem engineers and habitat disturbance, especially in the technosols of rehabilitated mines and forests undergoing restoration $[17,18]$.

Pheidole fallax is a predatory and carrion ant with Neotropical distribution, i.e., in the Greater Antilles, Central America, Colombia, Venezuela, and Brazil [19,20]. Studies have observed that $P$. fallax populations have many individuals cooperating during foraging, while the species has a worker that retrieves small particles of food and is responsible for mass recruitment [21]. They build nests (Figure 1) with a single entrance, with a gallery leading to several chambers near the surface of the ground, and a refuse pile on the outside [22]. These ants are some of the most abundant in sites under rehabilitation for long periods of time and in forests without mining [15]. The species also plays an important role as a seed disperser and predator [22]. Ants of the genus Pheidole (Subfamily: Mirmicinae) are considered effective ecosystem engineers; their nests can improve soil chemical characteristics through the transfer of substantial quantities of organic matter, like arthropod carcasses and plant debris [23].
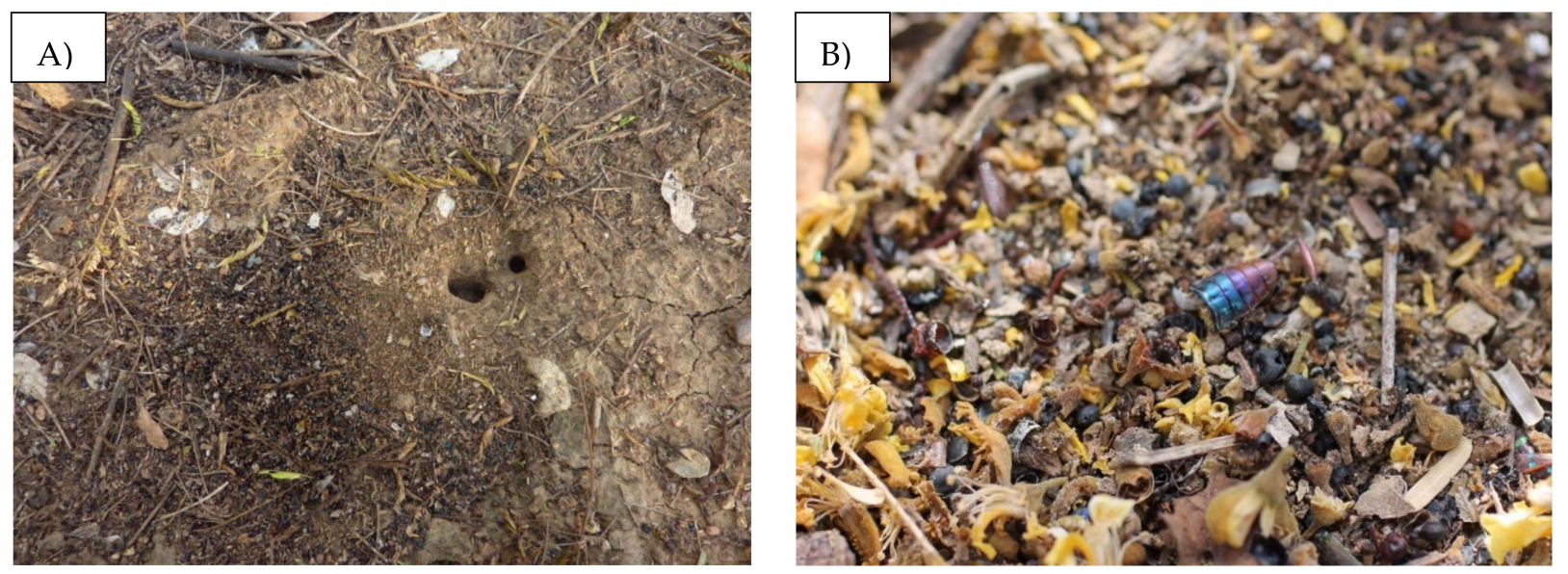

Figure 1. Photographs of (A) a P. fallax nest and (B) its refuse pile.

Considering the above information, in this study we aimed to test whether nests of $P$. fallax influence soil chemical properties, to characterize the organic debris found in the refuse piles, and to describe nest architecture as proxy of the bioturbation effect in rehabilitated sites of the Cerrejón coal mine (La Guajira, Colombia). We investigated whether the accumulation of arthropod carcasses and seeds in refuse piles contributes to soil nutrient enrichment. Additionally, we aimed to contribute knowledge on P. fallax by studying the structure of its nests. In summary, we aimed to (i) test whether $P$. fallax nests have an effect on soil chemical properties, (ii) characterize the debris of seeds, arthropods, and other organic items found in the refuse piles, and (iii) describe nest architecture as proxy of the bioturbation effect in the soil.

\section{Materials and Methods}

The study was carried out in the Cerrejón coal mine in the Department of La Guajira, in northern Colombia $\left(11^{\circ} 3^{\prime} \mathrm{N}, 72^{\circ} 44^{\prime} \mathrm{W}-11^{\circ} 8^{\prime} \mathrm{N}, 72^{\circ} 37^{\prime} \mathrm{W}\right)$, with altitudes between 200 and $240 \mathrm{~m}$ above sea level. The natural ecosystem surrounding the mine is a seasonal dry forest, with vegetation corresponding to sub-xerophytic and dry forest biotic zones, dominated by species such as Cordia alba, Mimosa arenosa, Caesalpinia mollis, and Prosopis juliflora. Precipitation is mainly bimodal with an annual mean of $800 \mathrm{~mm}$, evapotranspiration from 1000 to $1500 \mathrm{~mm}$, and mean annual temperature of $27.5^{\circ} \mathrm{C}$ [24]. 
The rehabilitation protocol used in the mine consisted of three stages: geomorphological adaptation of the terrain, topsoil stabilization with grasses, and revegetation with native species $[15,24]$.

\subsection{Location of Ant Nests}

Given the operational procedures used at the mine, one single rehabilitation plot is installed each year, resulting in sites with different rehabilitation lifetimes; from these, we selected two sites: 16 and 20 years. Three plots $(40 \times 5 \mathrm{~m})$ with a minimal distance of $300 \mathrm{~m}$ from each other were established in each site to locate nests of $P$. fallax. Following similar investigations [22,25], tuna baits ( $2 \mathrm{~g}$ ) were placed in the soil in each plot in a $3 \times 20 \mathrm{~m}$ grid. The ant workers that approached the baits were followed to identify the nest entrances.

\subsection{Characterization and Biomass of Organic Debris of Refuse Piles}

Fifteen nests (five per plot) were selected randomly from each site for characterization of the organic debris in refuse piles. All debris found in the refuse piles was collected following the procedure detailed below. In the laboratory, the organic debris was sorted into three groups: (a) carcasses or parts of arthropods (AD: arthropod debris), (b) seeds, and (c) parts of other animals (OAD: other animal debris), such as pupae and larvae of arthropods. Each sample was cleaned, dried, and weighed using an analytical balance.

\subsection{Chemical Properties of Ant Nets}

Given the availability of nests, only for the 20-year site (two plots), 10 nests were selected for near-infrared spectra (NIRS) analyses [26]; from these, 7 were adequate for chemical analyses (based on the size of the nests) and were assessed accordingly.

For the chemical analysis, in each nest, three types of samples were collected: (1) $400 \mathrm{~g}$ of soil from the entrance of nests at a depth of $10 \mathrm{~cm},(2)$ a sample from the refuse pile (sample size depending on the size of the refuse pile), and (3) a control sample obtained from soil located at least $1 \mathrm{~m}$ away from the nest's entrance. The control sample was collected following the same protocol as for Sample 1. The same protocol was followed in every nest, after having previously verified that there was no ant activity in the nest.

Chemical variables were measured: organic matter content, using the Walkley and Black volumetric method [27]; total phosphorus (P) (L-ascorbic spectrophotometry, UV-vis); $\mathrm{Ca}^{+2}, \mathrm{Mg}^{+2}$, and $\mathrm{K}^{+1}$ (1N ammonium acetate, atomic absorption); $\mathrm{pH}$ (in a 1v:2v water solution); total nitrogen, by a Micro-Kjeldahl method; and the effective cation exchange capacity (ECEC) as the sum of cations extracted with $1 \mathrm{~N}$ ammonium acetate [28].

To discriminate nest soil from surrounding soil using NIRS (750-2500 nm), two $10 \mathrm{~g}$ samples were taken from each nest, control soil, and refuse pile. Each sample was air-dried, crushed, and sieved at $500 \mu \mathrm{m}$. One gram of each sifted soil sample was further packed in a quartz-glass container and scanned with a spectrometer (NIRFLEX N 500, Buchi ${ }^{\circledR}$, Flawil, Switzerland) in the 1010-2550 nm spectral range. Measurements were taken at $4 \mathrm{~nm}$ intervals. The NIR spectra were obtained at $25{ }^{\circ} \mathrm{C}$ and $48 \%$ relative humidity.

The spectra represented the reflectance $(\mathrm{R})$ of re-emitted light as a function of the wavelength. Reflectance was converted to absorbance (A) using the equation:

$$
A=\log (1 / R)
$$

A data matrix of NIR spectral signals can be highly heterogeneous, and considerable variation of measured parameters may exist. Thus, data pre-treatment is a prerequisite to reduce the number of non-informative variables (descriptors). Our data matrix of raw NIR signals was transformed to the second derivative using second-order polynomial Savitzky-Golay smoothing as the spectral pre-treatment method. Finally, for data analysis, only reflectance measurements taken at $8 \mathrm{~nm}$ intervals were retained, in order to reduce the number of variables [29]. The software Unscrambler X 10.3 was used to obtain the second-derivative transformation. 


\subsection{Internal Structure of Nests and Calculation of Nest Volume}

The volume of soil removed by $P$. fallax for construction of the nests was estimated based on the nest's volume. Furthermore, nest architecture was described as follows: two nests from the 16-year site and three nests from the 20-year site were selected for description of the internal structure by three-dimensional models obtained by impregnation with dental gypsum (Wang et al., 1995). A suspension of $400 \mathrm{~g}$ of gypsum and $11 \mathrm{of}$ water was poured slowly in the nest using a needleless syringe. The gypsum molds were excavated two days later by digging $1 \mathrm{~m}$ deep from the nest's entrance, and the chambers were exposed horizontally, starting from the top.

The molds were measured to determine the total volume (TV), total height (TH), number of chambers (NC), and average volume of chambers (AVC). The TV was estimated by employing Archimedes' principle of fluid displacement: each nest was immersed in a beaker of $1000 \mathrm{cc}$, enough to be completely submerged, in order to register the volume displaced. The nests had been previously waterproofed with acrylic solution (SIKA ${ }^{\circledR}$, Baar, Switzerland) to seal pores in the castings. The AVC was calculated by measuring the length, width, and height of each chamber with a digital Vernier caliper [30].

\subsection{Data Analysis}

The biomass of organic debris found in the refuse piles (seeds, AD, OAD) of each site was compared via a non-parametric Kruskal-Wallis $\mathrm{H}$ test and subsequent post hoc Dunn test with Bonferroni adjustment; the analyses were performed using the PMCMRplus package in R [31]. To compare the total biomass between sites, considering the items (seeds, AD, OAD) as blocks, a non-parametric Friedman test was performed with replicated blocked data and chi-square statistics using the muStat package [32].

A Kruskal-Wallis test and, subsequently, a post hoc Dunn test with Bonferroni adjustment for multiple comparisons were used to compare chemical variables among the interior of nests, the control soil, and the refuse piles. Principal component analysis (PCA) for NIRS and a permutation test (Monte Carlo with 999 simulations) were performed to test the differences among factors. All these analyses were performed using the ade4 package in $\mathrm{R}$ [33].

\section{Results}

\subsection{Characterization and Biomass of Organic Debris in Refuse Piles}

The 15 selected $P$. fallax nests were characterized by one to three elongated-oval entrances. The refuse piles had a radius of approximately $30 \mathrm{~cm}$ around the nest. Some nests were covered with the remains of branches and dry leaves, creating a barrier around the nest; however, the ants left a small space for foraging activities.

The refuse piles of both sites were composed mainly of AD and seeds (Figure 2 and Table 1); both items constituted $96 \%$ of the organic debris biomass found in the nests. The AD contents were greater than the other items in the 20-year site (Dunn's test $p<0.05$ ), while in the 16-year site, AD contents were barely different from OAD contents (Dunn's test $p<0.05$, Table 1 ). The biomass of items from the 20-year site was significantly greater (Friedman test, $2=29.15, \mathrm{df}=1, p$-value $<0.001$ ). Most debris observed corresponded to carcasses of Coleoptera, Hymenoptera, and Orthoptera species. The remains of ants of the Cephalotes genus were present in $100 \%$ of the nests. Seeds of grasses and legumes were the second most observed items in the refuse pile. The most frequently collected items composing the OAD were pupae, herbivore feces, larvae, and mollusk shells (Figure 2 and Table 1). 


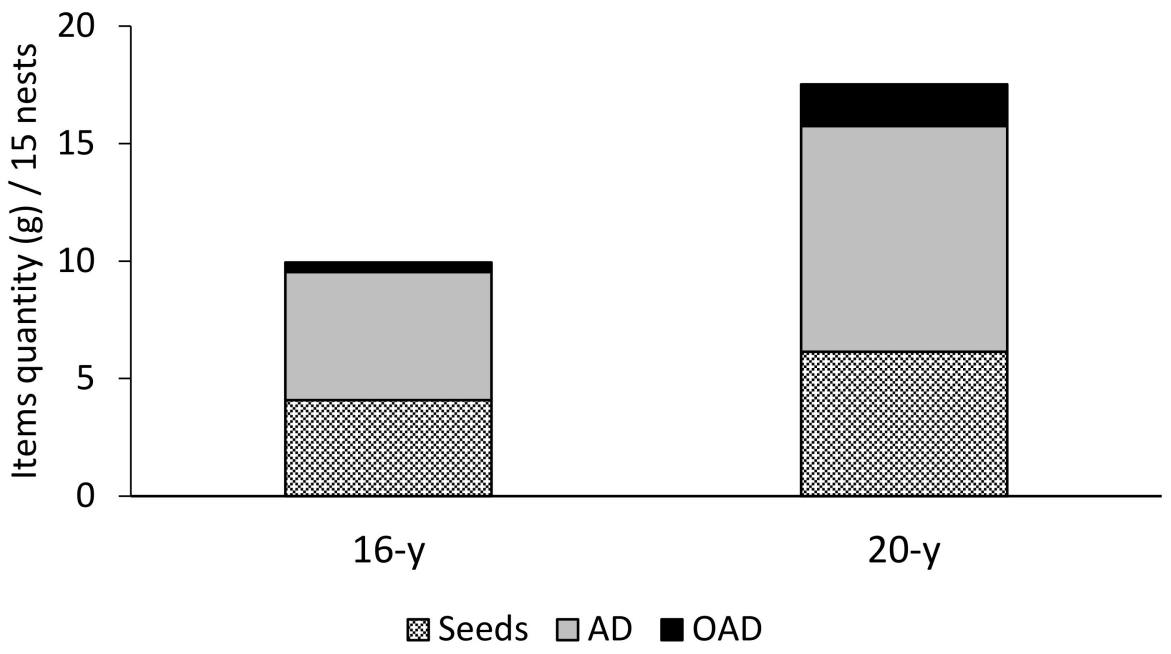

Figure 2. Biomass (g) of three item types found in 15 coal mine refuse piles colonized by P. fallax in 16-year and 20-year rehabilitated sites of the Cerrejón mine in La Guajira, Colombia. AD = arthropod debris; $\mathrm{OAD}=$ other animal debris.

Table 1. Mean and standard error (SE, given in italics) of organic debris found in refuse piles of P. fallax determined by the Kruskal-Wallis test and post hoc comparisons using the Dunn test. Different letters denote statistically significant differences between study sites. $n=$ number of nests; $\mathrm{AD}=$ arthropod debris; $\mathrm{OAD}=$ other animal debris.

\begin{tabular}{cccccc}
\hline Site & $\boldsymbol{n}$ & Seeds $(\mathrm{g})$ & AD $(\mathrm{g})$ & OAD $(\mathrm{g})$ & $p$-Value \\
\hline 16 years & 15 & $0.27 \mathrm{a}$ & $0.36 \mathrm{~b}$ & $0.03 \mathrm{~b}$ & 0.001 \\
& & 0.09 & 0.07 & 0.01 & \\
20 years & 15 & $0.41 \mathrm{a}$ & $0.64 \mathrm{a}$ & $0.12 \mathrm{~b}$ & 0.001 \\
& & 0.20 & 0.21 & 0.03 & \\
\hline
\end{tabular}

\subsection{Chemical and NIRS Analyses}

Refuse pile samples of P. fallax were different from the nest's interior soil and from the surrounding soil. However, the interior nest soil did not differ from the control soil. The contents of $\mathrm{N}, \mathrm{P}, \mathrm{K}, \mathrm{Mg}$, and $\mathrm{OM}$ were significantly higher in soils from the refuse piles, where the $\mathrm{pH}$ was 14 to $70 \%$ greater than that of the control soil. Likewise, refuse piles had lower $\mathrm{pH}$ levels and lower $\mathrm{Ca}$ contents than control soils, with a significant difference only for $\mathrm{pH}$ levels (Table 2).

Table 2. Chemical properties (mean and standard error, SE) of soils collected from $P$. fallax $(n=7)$ nests, refuse piles, and control soil from rehabilitated sites of the Cerrejón mine, located in La Guajira, Colombia. The Kruskal-Wallis test was performed, along with post hoc comparisons using the Dunn test. An increase or decrease in the values for refuse piles (RP) with respect to the control soil (CS) is indicated as a percentage and with arrows.

\begin{tabular}{|c|c|c|c|c|c|c|c|c|c|}
\hline & \multicolumn{2}{|c|}{ Refuse Pile } & \multicolumn{2}{|c|}{ Nests } & \multicolumn{2}{|c|}{ Control Soil } & \multicolumn{3}{|c|}{$\begin{array}{c}\text { Increase/Decrease } \\
\text { RP vs. CS (\%) }\end{array}$} \\
\hline & Mean & SE & Mean & SE & Mean & SE & $\mathbf{P}$ & & \\
\hline $\mathrm{pH}$ & $6.70 \mathrm{a}$ & 0.17 & $7.83 \mathrm{~b}$ & 0.15 & $7.84 \mathrm{~b}$ & 0.06 & $<0.01$ & $\downarrow$ & 14.54 \\
\hline OM (\%) & $9.36 \mathrm{a}$ & 1.30 & $3.32 \mathrm{~b}$ & 0.10 & $3.28 \mathrm{~b}$ & 0.31 & $<0.01$ & $\uparrow$ & 64.96 \\
\hline $\mathrm{N}(\%)$ & $0.98 \mathrm{a}$ & 0.29 & $0.30 \mathrm{~b}$ & 0.10 & $0.29 \mathrm{~b}$ & 0.07 & $<0.01$ & $\uparrow$ & 70.41 \\
\hline $\mathrm{P}(\mathrm{ppm})$ & $132.29 \mathrm{a}$ & 7.85 & $46.54 \mathrm{~b}$ & 9.31 & $54.11 \mathrm{~b}$ & 13.03 & $<0.01$ & $\uparrow$ & 59.10 \\
\hline $\mathrm{Ca}$ (meq) & $39.19 \mathrm{a}$ & 7.28 & $56.60 \mathrm{~b}$ & 8.53 & $54.6 \mathrm{~b}$ & 8.31 & & & \\
\hline Mg (meq) & 10.13 a & 1.14 & $4.28 \mathrm{~b}$ & 0.19 & $4.36 \mathrm{~b}$ & 0.25 & $<0.01$ & $\uparrow$ & 56.96 \\
\hline $\mathrm{K}(\mathrm{meq})$ & $5.43 \mathrm{a}$ & 0.31 & $2.46 \mathrm{~b}$ & 0.16 & $2.53 \mathrm{~b}$ & 0.25 & $<0.01$ & $\uparrow$ & 53.41 \\
\hline
\end{tabular}


A separation of the refuse piles from the control and nest soils was observed in the PCA results (Figure 3). However, in this case, the NIRS analyses distinguished nest soils from control soils (the barycenters are separated). The first component (21.3\% variance explained) separated the sampling plots and showed high variability, while the second component (12.3\% variance explained) distinguished the soil's origin. The refuse piles formed a separate group ( $p<0.01,3.5 \%$ variance explained by the Monte Carlo test) (Figure 3).

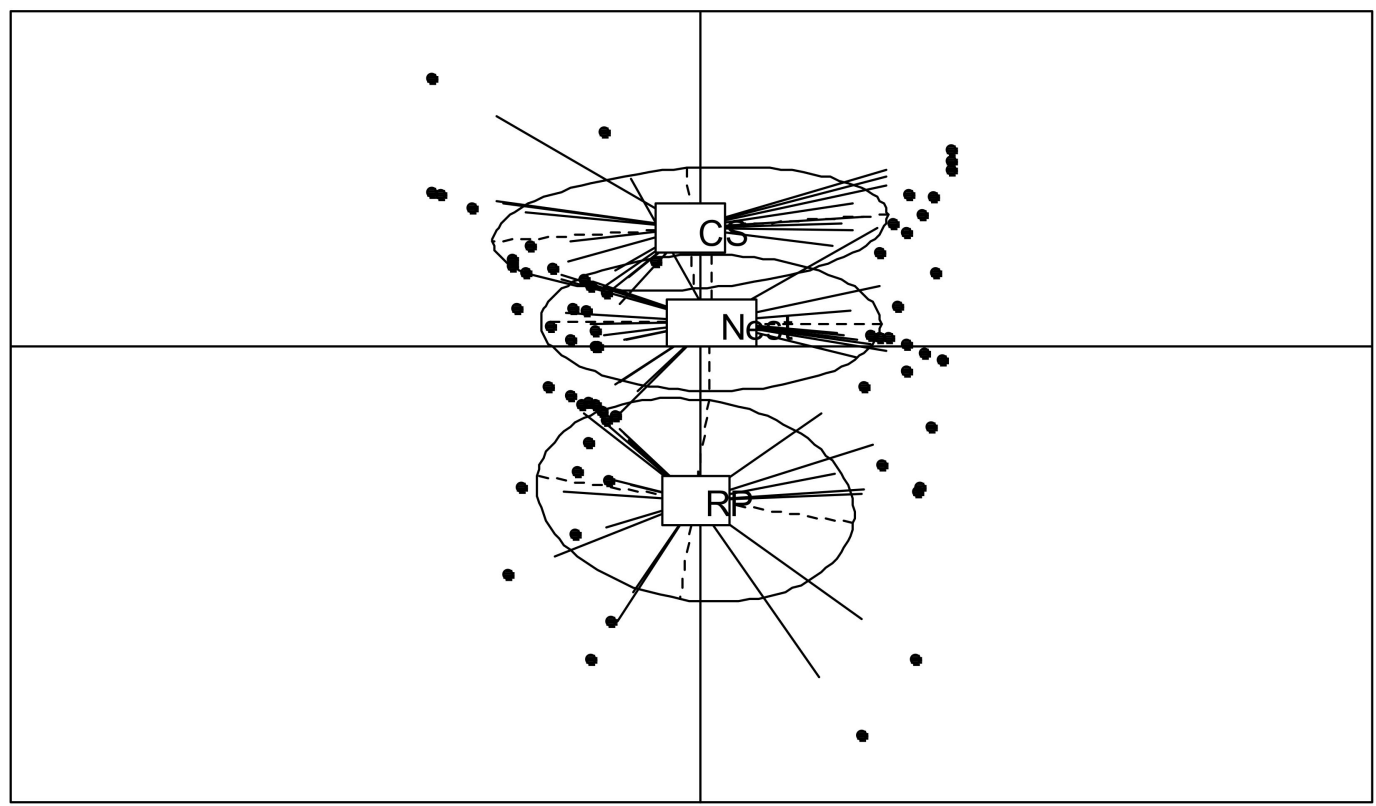

Figure 3. Principal component analysis results for projection of NIRS spectra of refuse piles (RP), soil of $P$. fallax nests, and control soil (CS), in the plane defined by the first two factors for the 20-year site.

\subsection{Nest Architecture}

The P. fallax colonies had one to four irregular nest entrances, surrounded by a clean area for foraging. Nest molds presented an asymmetric architecture, with the chambers having irregularly shaped edges. These chambers were interconnected with wide horizontal and vertical tunnels. Nest height ranged from 4.7 to $10.3 \mathrm{~cm}$ (corresponding to depths in the soil), each with 7 to 17 chambers, and an average of 11.8 chambers per nest. The most superficial chambers were found $2 \mathrm{~cm}$ below the soil surface. The nests had a TV ranging from 30.4 to $105.7 \mathrm{~cm}^{3}$ (Table 3 and Figure 4).

Table 3. Mean measurements ( \pm standard error), for the number of chambers (NCs), total height $(\mathrm{TH})$, total volume (TV), and average volume of chambers (AVC) of five P. fallax nests.

\begin{tabular}{ccccc}
\hline Nest & NC & TH $\mathbf{( c m )}$ & TV $\left.\mathbf{( c m}^{3}\right)$ & AVC \\
\hline 1 & 7 & 4.7 & 30.4 & $16.66 \pm 0.62$ \\
2 & 9 & 6.2 & 40.1 & $12.08 \pm 0.29$ \\
3 & 12 & 8.4 & 55.6 & $15.94 \pm 0.11$ \\
4 & 14 & 8.9 & 90.4 & $14.13 \pm 0.15$ \\
5 & 17 & 10.3 & 105.7 & $17.41 \pm 0.39$ \\
\hline
\end{tabular}




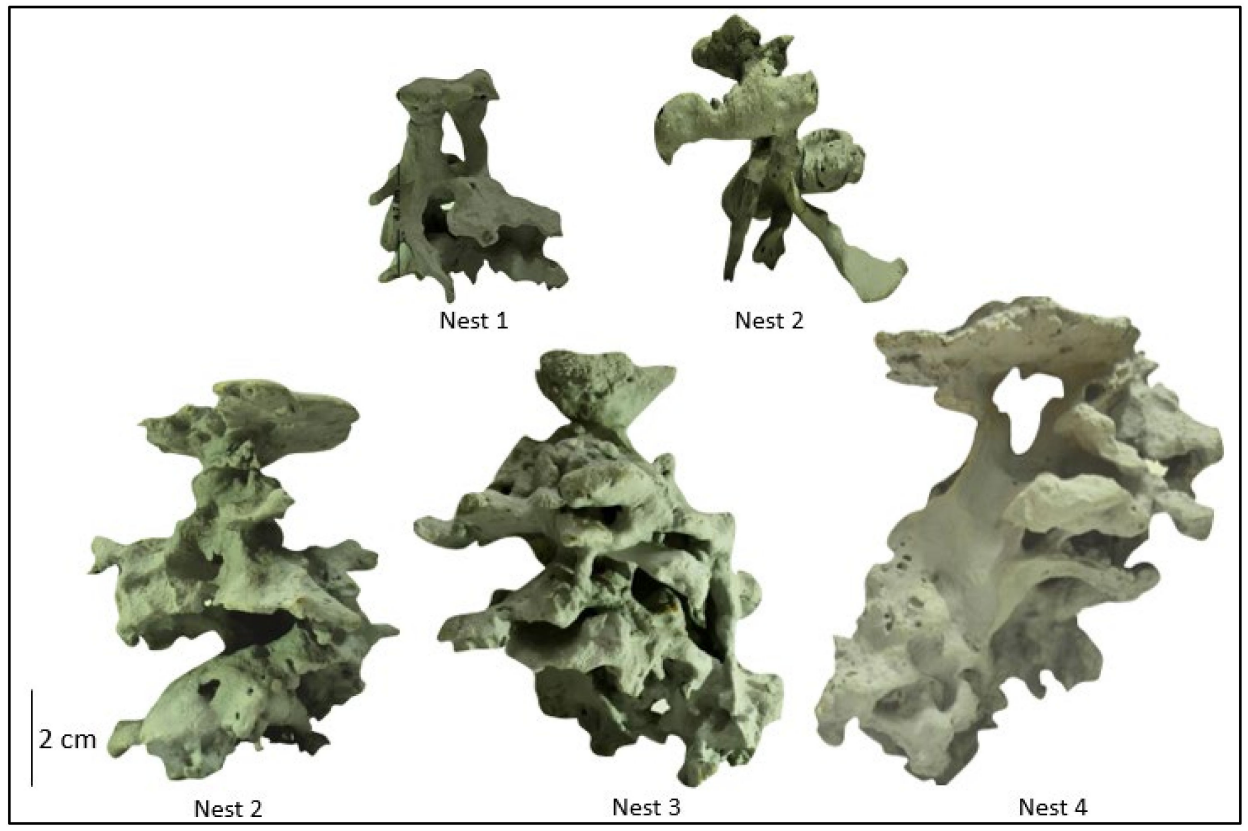

Figure 4. P. fallax nests molded with dental gypsum, showing the ant nest architecture in rehabilitated sites of the Cerrejón mine in La Guajira, Colombia.

\section{Discussion}

Aspects of the biology of $P$. fallax have been described mainly in forest and agroecosystems. This work, along with that of other researchers $[15,22,25]$, seeks to understand the role of this species in rehabilitated coal mine areas. The results of this study show that the bioturbation made by these ants can improve the soil conditions through nest building and maintenance, but also by accumulating organic debris.

Data obtained from external refuse piles suggest that $P$. fallax colonies use food resources of different trophic levels, with arthropods and seeds being the main foods in their diet. These results are consistent with results of other studies in which P. fallax workers have been identified collecting seeds and insect carcasses, which are then carried inside the nests and later deposited in the refuse pile [23].

The greater amount of arthropod and seed remains found in refuse piles in the 20-year-old site, compared to the 16-year-old site, could indicate a greater supply of resources. It is important to highlight that the four additional years at the 20-year-old site are not the reason for the greater supply of resources. Maybe this difference is more related to better habitat conditions at the 20-year-old site, which promote the establishment of a greater number of nests both for this species [15,25] and for others [14,34]. Furthermore, species of the Pheidole genus have small foraging areas $( \pm 7 \mathrm{~m})$ [35], which would indicate that the resources collected are close to where the nests are located.

The hauling of corpses and seeds to the nests could trigger the incorporation of nutrients into the soil, causing an enrichment of the adjacent edaphic horizons [17,23]. This assertion coincides with the results of chemical analysis, where the composition of refuse piles was different when compared to the surrounding soil and interior of nests. In other words, high levels of organic matter showed that the entrance of the nest is an important location for the accumulation, translocation, and transformation of soil organic matter [23]. Refuse piles were also identified as sites with lower $\mathrm{pH}$ as compared to the surrounding soil. Other nutrients, such as $\mathrm{P}, \mathrm{K}, \mathrm{N}$, and $\mathrm{Mg}$, are also elevated in the refuse piles according to other studies with ant nests [36-38]. NIRS is a practical technique that allowed us to distinguish among refuse pile soil, soil from the interior of the nest, and soil surrounding the P. fallax nests, thus evidencing modifications in soil organic matter content as a result of ant activity. Similar values for the nest interior and control soil may be explained by bioturbation and mixing of soil particles, leading to a reduction or homogenization of 
the nutrient content $[39,40]$. However, NIRS is a practical technique that allowed us to distinguish not only refuse pile soil from other types, but also soil from the interior of the nest from soil surrounding the $P$. fallax nests, although the difference between these was not lower. This is evidence of modifications in soil organic matter content as a result of ant activity, supporting the usefulness of NIRS spectra in identifying the origin of biogenic structures [29,41,42].

The architecture of ant nests has been mostly studied in fungus-feeding ants such as Paraponera, Pognomyrmex, Odontomachus, Camponotus, and Ectatomma [30,43]. However, the nest architecture of only a few species of the Pheidole genus has been studied, as is the case of $P$. oxyops [44]. The $P$. fallax nests analyzed presented a different architecture from those of $P$. oxyops, which have irregular and vertically structured nests with convex chambers at the top, concave chambers at the bottom, and a mean depth of $223.77 \mathrm{~cm} \mathrm{[44].} \mathrm{P.} \mathrm{fallax} \mathrm{nests} \mathrm{are}$ shallow, not exceeding $10 \mathrm{~cm}$, and the chambers are irregular. However, some nests had a concave top chamber. Deeper ant nests have been found in non-compacted soils with little anthropogenic intervention [43]. The soils examined by Tschinkel [43] did not present high bulk density values, but our rehabilitated sites have a soil layer about $30 \mathrm{~cm}$ deep, which could be a limitation to building deeper nests [45]. Another possible explanation could be related to the size of the colony, although this was not evaluated. The high rate of soil turnover found in the study area [25] could explain why nests do not reach larger sizes.

Some generalist ant species have been documented to not have a specific construction pattern, which would coincide with $P$. fallax presenting irregular patterns in the architecture of its nests, unlike fungus-eating ants, which build more elaborate and deeper nests than detritus-/seed-collecting ants [46]. Also, providing information on the internal structure of nests and on the calculation of the nest volume may be relevant for hydrological studies; channels and large burrows may function as macropores, thus creating the potential for rapid movement of water and water-soluble chemicals, namely, preferential flow, into the soil $[5,47,48]$. Bioturbation generated by nest construction results in soil physical changes such as a reduction in the soil bulk density, redistribution of particles (i.e., small size in refuse piles), and the creation of lateral and vertical pore networks, which alter soil porosity and water infiltration [23,49]. However, it is necessary to determine the rate of soil mobilized in the building of the nest to evaluate with greater accuracy the ecosystem service offered by these ants in relation to bioturbation.

The transport of arthropods, seeds, and other items may effectively contribute to processes such as nutrient and seed dispersal, and the nests may act as "fertility islands" $[15,19,20,46]$. Also, the accumulation of organic matter can attract soil microarthropods and protozoa [38], such as Acari and Collembolas, which were found in the refuse piles. On the other hand, some of these seeds were viable; indeed, seeds found in the nests and refuse pile have greater potential to germinate than those located in the soil far from the nests [22,50], which might enhance ecological restoration processes in shorter periods of time. However, it is necessary to assess whether the increase in nutrient availability improves plant growth [23].

\section{Conclusions}

We can conclude that $P$. fallax contributes to the soil nutrient pool through the accumulation of organic debris in its refuse piles. The present results further illustrate that chemical modifications inside the nest were minor and could only be determined by NIRS analysis. Future studies should take samples directly from the chambers. For the first time, the internal architecture of the nests is described, contributing to the knowledge of the biology of this species. The determination of the volume of the nests gives indications of the volume of soil that is required for their construction. A more complete quantification of the bioturbation impact is recommended.

By combining this study with others carried out with P. fallax in this mine, the role of this species in the re-establishment of ecological processes, such as soil organic matter accumulation, seed dispersion, and bioturbation, can be highlighted. It is possible that the 
high turnover of nests leads to nutrient-rich patches, contributing to soil heterogeneity. All these processes are important elements for monitoring in ecological restoration projects.

Author Contributions: Y.D.-H. wrote the initial draft. B.P.G.-R. and Y.B.-T. participated in the design of the study and carried out the data collection. J.J.J. analyzed the data. S.E.L.-B. and M.C. revised, discussed, modified, and supplemented the ideas for the final draft. All authors have read and agreed to the published version of the manuscript.

Funding: This research was funded by a COLCIENCIAS grant (Colombia), (Code: 1116-569-34827) and "Vicerrectoría de Investigaciones Extensión y Proyección Social" of Universidad del Atlántico. Sergio Esteban Lozano-Baez acknowledges financial support from the Colombian Ministry of Science (Grant No. 848).

Acknowledgments: Special thanks to "Departamento de Seguridad y Gestión Ambiental" of "Cerrejón" for their logistical assistance; to Yair Barros for field assistance; and to Simone Di Prima and to Inge Armbrecht for comments on an earlier draft of the manuscript. The ARAID foundation is acknowledged for their support provided to Juan J. Jiménez.

Conflicts of Interest: The authors declare no conflict of interest.

\section{References}

1. Mansourian, S.; Vallauri, D.; Dudley, N. Forest Restoration in Landscapes: Beyond Planting Trees; Springer: New York, NY, USA, 2005; ISBN 978-0-387-25525-5.

2. Dominati, E.; Patterson, M.; Mackay, A. A framework for classifying and quantifying the natural capital and ecosystem services of soils. Ecol. Econ. 2010, 69, 1858-1868. [CrossRef]

3. Prach, K.; Hobbs, R.J. Spontaneous succession versus technical reclamation in the restoration of disturbed sites. Restor. Ecol. 2008, 16, 363-366. [CrossRef]

4. Lavelle, P.; Spain, A.; Blouin, M.; Brown, G.; Decaëns, T.; Grimaldi, M.; Jiménez, J.J.; McKey, D.; Mathieu, J.; Velasquez, E.; et al. Ecosystem engineers in a self-organized soil: A Review of concepts and future research questions. Soil Sci. 2016, 181, 91-109. [CrossRef]

5. $\quad$ Lozano-Baez, S.E.; Domínguez-Haydar, Y.; Meli, P.; Meerveld, I.; Vásquez, K.V.; Castellini, M. Key gaps in soil monitoring during forest restoration in Colombia. Restor. Ecol. 2021, 29, e13391. [CrossRef]

6. Jones, C.G.; Lawton, J.H.; Shachak, M. Organisms as ecosystem engineers. Oikos 1994, 69, 373. [CrossRef]

7. Lee, K.; Foster, R. Soil Fauna and Soil Structure. Soil Res. 1991, 29, 745. [CrossRef]

8. Dauber, J.; Niechoj, R.; Baltruschat, H.; Wolters, V. Soil engineering ants increase grass root arbuscular mycorrhizal colonization. Biol. Fertil. Soils 2008, 44, 791-796. [CrossRef]

9. Folgarait, P.J. Ant biodiversity and its relationship to ecosystem functioning: A review. Biodivers. Conserv. 1998, 7, 1221-1244. [CrossRef]

10. Eldridge, D. Effect of ants on sandy soils in semi-arid eastern Australia-Local distribution of nest entrances and their effect on infiltration of water. Soil Res. 1993, 31, 509. [CrossRef]

11. Jiménez, J.J.; Decaëns, T.; Lavelle, P. C and N concentrations in biogenic structures of a soil-feeding termite and a fungus-growing ant in the Colombian savannas. Appl. Soil Ecol. 2008, 40, 120-128. [CrossRef]

12. Lobry de Bruyn, L.A. Ants as bioindicators of soil function in rural environments. Agric. Ecosyst. Environ. 1999, 74, $425-441$. [CrossRef]

13. Andersen, A.N.; Majer, J.D. Ants show the way down under: Invertebrates as bioindicators in land management. Front. Ecol. Environ. 2004, 2, 291-298. [CrossRef]

14. Buchori, D.; Rizali, A.; Rahayu, G.A.; Mansur, I. Insect diversity in post-mining areas: Investigating their potential role as bioindicator of reclamation success. Biodiversitas 2018, 19, 1696-1702. [CrossRef]

15. Domínguez-Haydar, Y.; Armbrecht, I. Response of ants and their seed removal in rehabilitation areas and forests at El Cerrejón coal mine in Colombia. Restor. Ecol. 2011, 19, 178-184. [CrossRef]

16. Menta, C.; Conti, F.D.; Pinto, S.; Leoni, A.; Lozano-Fondón, C. Monitoring soil restoration in an open-pit mine in northern italy. Appl. Soil Ecol. 2014, 83, 22-29. [CrossRef]

17. Frouz, J.; Holec, M.; Kalčík, J. The Effect of Lasius Niger (Hymenoptera, Formicidae) ant nest on selected soil chemical properties. Pedobiologia 2003, 47, 205-212. [CrossRef]

18. Philpott, S.M.; Perfecto, I.; Armbrecht, I.; Parr, C.L. Ant diversity and function in disturbed and changing habitats. In Ant Ecology; Lach, L., Parr, C., Abbott, K., Eds.; Oxford University Press: Oxford, UK, 2009; pp. 137-156, ISBN 978-0-19-954463-9.

19. Leal, I.R.; Wirth, R.; Tabarelli, M. Seed dispersal by ants in the Semi-Arid Caatinga of North-East Brazil. Ann. Bot. 2007, 99, 885-894. [CrossRef]

20. Lôbo, D.; Tabarelli, M.; Leal, I. Relocation of Croton sonderianus (Euphorbiaceae) seeds by Pheidole fallax Mayr (Formicidae): A case of post-dispersal seed protection by ants? Neotrop. Entomol. 2011, 40, 440-444. [CrossRef] 
21. Itzkowitz, M.; Haley, M. The food retrieval tactics of the ant Pheidole fallax Mayr. Insectes Sociaux 1983, 30, 317-322. [CrossRef]

22. Gutierrez Rapalino, B.P.; Domínguez Haydar, Y.D.C. Contribución de Pheidole fallax y Ectatomma ruidum (Hymenoptera: Formicidae) en la dispersión y germinación de semillas en áreas rehabilitadas de la mina de Carbón Del Cerrejón, Colombia. Rev. Biol. Tropical 2017, 65, 575-587. [CrossRef]

23. Shukla, R.K.; Singh, H.; Rastogi, N.; Agarwal, V.M. Impact of abundant Pheidole ant species on soil nutrients in relation to the food biology of the species. Appl. Soil Ecol. 2013, 71, 15-23. [CrossRef]

24. Gualdrón Acosta, R. Cerrejón: Hacia La Rehabilitación de Las Tierras Intervenidas Por La Minería a Cielo Abierto; Cerrejón: Bogotá, Colombia, 2011; ISBN 978-958-99731-8-9.

25. Domínguez-Haydar, Y.; Gutierrez-Rapalino, B.; Jiménez, J.J. Density and spatial distribution of nests of Ectatomma ruidum and Pheidole fallax (Hymenoptera: Formicidae), as response to the recovery of coal mine areas. Sociobiology 2018, 65, 415. [CrossRef]

26. Ben-Dor, E.; Banin, A. Near-infrared analysis as a rapid method to simultaneously evaluate several soil properties. Soil Sci. Soc. Am. J. 1995, 59, 364-372. [CrossRef]

27. Walkley, A.; Black, I.A. An examination of the degtjareff method for determining soil organic matter, and a proposed modification of the chromic acid titration method. Soil Sci. 1934, 37, 29-38. [CrossRef]

28. EMBRAPA. Manual of methods of soil Analysis, 2nd ed.; Embrapa Soils: Rio de Janeiro, Brazil, 2011.

29. Zangerlé, A.; Hissler, C.; Blouin, M.; Lavelle, P. Near infrared spectroscopy (nirs) to estimate earthworm cast age. Soil Biol. Biochem. 2014, 70, 47-53. [CrossRef]

30. De Carvalho Guimarães, I.; Pereira, M.C.; Batista, N.R.; Rodrigues, C.A.P.; Antonialli, W.F. The complex nest architecture of the Ponerinae ant Odontomachus chelifer. PLoS ONE 2018, 13, e0189896. [CrossRef]

31. Pohlert, T. The Pairwise Multiple Comparison of Mean Ranks Package (PMCMRplus). Available online: https:/ / cran.r-project. org/web/packages/PMCMRplus/PMCMRplus.pdf (accessed on 23 January 2022).

32. Wittkowski, K.M.; Song, T. Package MuStat: Prentice Rank Sum Test and McNemar Test. Available online: https://cran.r-project. $\mathrm{org} /$ web/packages/muStat/muStat.pdf (accessed on 23 January 2022).

33. R Core Team. R: A Language and Environment for Statistical Computing; R Foundation for Statistical Computing: Viena, Austria, 2021.

34. Majer, J.D. Animals in the restoration process-progressing the trends. Restor. Ecol. 2009, 17, 315-319. [CrossRef]

35. Agarwal, V.M.; Rastogi, N.; Raju, S.V.S. Impact of predatory ants on two Lepidopteran insect pests in Indian cauliflower agroecosystems. J. Appl. Entomol. 2007, 131, 493-500. [CrossRef]

36. Cammeraat, L.H.; Willott, S.J.; Compton, S.G.; Incoll, L.D. The effects of ants' nests on the physical, chemical and hydrological properties of a rangeland Soil in Semi-Arid Spain. Geoderma 2002, 105, 1-20. [CrossRef]

37. Moutinho, P.; Nepstad, D.C.; Davidson, E.A. Influence of leaf-cutting ant nests on secondary forest growth and soil properties in amazonia. Ecology 2003, 84, 1265-1276. [CrossRef]

38. Wagner, D.; Brown, M.J.F.; Gordon, D.M. Harvester Ant nests, soil biota and soil chemistry. Oecologia 1997, 112, 232-236. [CrossRef] [PubMed]

39. Holec, M.; Frouz, J. The effect of two ant species lasius niger and lasius flavus on soil properties in two contrasting habitats. Eur. J. Soil Biol. 2006, 42, S213-S217. [CrossRef]

40. Levan, M.A.; Stone, E.L. Soil modification by colonies of black meadow ants in a New York old field. Soil Sci. Soc. Am. J. 1983, 47, 1192. [CrossRef]

41. Domínguez-Haydar, Y.; Velásquez, E.; Zangerlé, A.; Lavelle, P.; Gutiérrez-Eisman, S.; Jiménez, J.J. Unveiling the age and origin of biogenic aggregates produced by earthworm species with their NIRS Fingerprint in a Subalpine Meadow of Central Pyrenees. PLoS ONE 2020, 15, e0237115. [CrossRef] [PubMed]

42. Velasquez, E.; Pelosi, C.; Brunet, D.; Grimaldi, M.; Martins, M.; Rendeiro, A.C.; Barrios, E.; Lavelle, P. This ped is my ped: Visual separation and near infrared spectra allow determination of the origins of soil macroaggregates. Pedobiologia 2007, 51, 75-87. [CrossRef]

43. Tschinkel, W.R. The nest architecture of the ant, camponotus socius. J. Insect Sci. 2005, 5, 9. [CrossRef]

44. Forti, L.C.; Camargo, R.S.; Fujihara, R.T.; Lopes, J.F.S. The nest architecture of the ant, Pheidole oxyops Forel (Hymenoptera: Formicidae). Insect Sci. 2007, 14, 437-442. [CrossRef]

45. Domínguez-Haydar, Y.; Velásquez, E.; Carmona, J.; Lavelle, P.; Chavez, L.F.; Jiménez, J.J. Evaluation of reclamation success in an open-pit coal mine using integrated soil physical, chemical and biological quality indicators. Ecol. Indic. 2019, 103, 182-193. [CrossRef]

46. Farji-Brener, A.G.; Werenkraut, V. The effects of ant nests on soil fertility and plant performance: A meta-analysis. J. Anim. Ecol. 2017, 86, 866-877. [CrossRef]

47. Leite, P.A.M.; Carvalho, M.C.; Wilcox, B.P. Good ant, bad ant? Soil engineering by ants in the brazilian caatinga differs by species. Geoderma 2018, 323, 65-73. [CrossRef]

48. Wang, D.; Lowery, B.; Norman, J.M.; McSweeney, K. Ant burrow effects on water flow and soil hydraulic properties of sparta sand. Soil Tillage Res. 1996, 37, 83-93. [CrossRef]

49. Nkem, J.N.; Lobry de Bruyn, L.A.; Grant, C.D.; Hulugalle, N.R. The impact of ant bioturbation and foraging activities on surrounding soil properties. Pedobiologia 2000, 44, 609-621. [CrossRef]

50. O'Grady, A.; Breen, J.; Harrington, T.J.; Courtney, R. The seed bank in soil from the nests of grassland ants in a unique limestone grassland community in Ireland. Ecol. Eng. 2013, 61, 58-64. [CrossRef] 